\title{
Characterization of Conventional Cooking Stoves in South Eastern Nigeria
}

\author{
R. S. Bello ${ }^{1}$, M. A. Onilude ${ }^{2}$ \\ ${ }^{1}$ Department of Agricultural \& Bio-Environmental Engineering Technology, \\ Federal College of Agriculture, Ishiagu, Ebonyi State, Nigeria \\ ${ }^{2}$ Department of Agricultural and Environmental Engineering, University of Ibadan, Nigeria
}

\begin{abstract}
Performance characterization of some selected conventional cook stoves in South Eastern Nigeria had been carried out. Three conventional cook stoves (3-stone stove, charcoal stove and sawdust stove) were selected and evaluated. Their performances were compared with those of improved stove. The results show that the time spent in cooking $1 \mathrm{Kg}$ of rice/(yam) is significantly different in all the conventional stoves under test; (maximum $0.75(0.44) \mathrm{kg} / \mathrm{hr}$ for 3-stone stove and minimum $0.61(0.35) \mathrm{hr} / \mathrm{kg}$ for charcoal). Fuel utilization also differs for instance lesser quantity of charcoal would be required to cook the same quantity of food on the charcoal stove than the open fire stove. Also the specific fuel consumption value of charcoal stove is lesser than all other stoves. The 3stone stove have higher specific fuel consumption values indicative of more fuel consumption but lower thermal efficiency. This indicates a poor performance when compared to other improved stoves such as kerosene stove with higher thermal efficiency of $64.38 \%$.
\end{abstract}

Keywords: Cook stove; Fuel consumption; Thermal efficiency; Burn rate

\section{INTRODUCTION}

Over $60 \%$ of Nigeria's population depends on fuelwood and charcoal for cooking and other domestic energy needs (Olorunnisola, 1999). The energy consumed per capita was in the past used as an indicator of progress in stove development. In countries in Africa, charcoal is widely available and is thus used to almost the same extent as wood fuels. However, it was recognized in the nineties that it is not necessarily the amount of energy provided that mattered but the quality of the energy services needed at a certain development stage and its distribution. While better stoves may save energy, they will not by themselves prevent deforestation, though they may help slow it.

Cookstove technology and development have been studied on a continuing basis for over 35 years; unfortunately, there exist today no clear-cut internationally accepted design standards for biomass burning stove (Stout and Best, 2001). Worse still, the currently available local stoves do not usually represent the best designs that modern engineering can offer. However, the increasing interest on climate change and global warming issues has created awareness on the environmental and social costs of using traditional stoves.

The challenge of cook stove design is not only a technical issue but a social issue as well. How and what we cook greatly depends on our culture, lifestyle and resources. A good stove should be able to boil water quickly, simmer foods and cook an almost infinite variety 
of foods in different ways depending on the culture while minimizing fuel use and emissions produced.

Research results so far show that one stove may be efficient, another may heat faster, another safer, and each of them pollutes more or less than the other (Ernestine, 2008). It therefore depends on the stove designer to pick out a design that will best suit the locality and food types for which it is intended. Lack of access to appropriate energy sources is undoubtedly one of the roots of poverty which hinders economic and social development.

Many rural household in South Eastern Nigeria use traditional cooking stoves often, the use of firewood, agro-residues and cow-dung as fuel, have certain inherent defects in the environment (Bouttete, 1981). This paper presents performance characteristics of some tested traditional cooking stoves in South Eastern Nigeria and a comparison with improved stove.

\section{MATERIALS AND METHODS}

Several designs off cook stoves are identified in the local market, majority of which utilizes fuelwood, sawdust, and charcoal and kerosene as fuel. Three stove models were chosen based on the following criteria:

- Type of fuel burn

- Widespread coverage or acceptability factor having aesthetic design

- Unit price at the local market

- Locally available and in use for cooking

Fuel materials were sourced locally; sawdust from the carpentry workshop, charcoal from the open market and the rice husk from the rice processing centers. The sawdust and charcoal were screened for impurities and metals and dried under sun to remove the moisture content for proper combustion and also the elimination of smoke emission during burning.

\section{1. Material Description}

\section{A. Cook Stoves}

Two types of traditional stoves; 3-stones wood fire stoves and metal stoves (charcoal, sawdust/rice husk) and a kerosene stove was used in the test. A description of each stove is presented below.

\section{3-stone open fire stoves:}

This stove comprises of three set of materials arranged such that it could accommodate any specific size of pot. The stove support the cooking pot over the centre of the fire, the stove was arranged so that the pot sits partly down between them. 


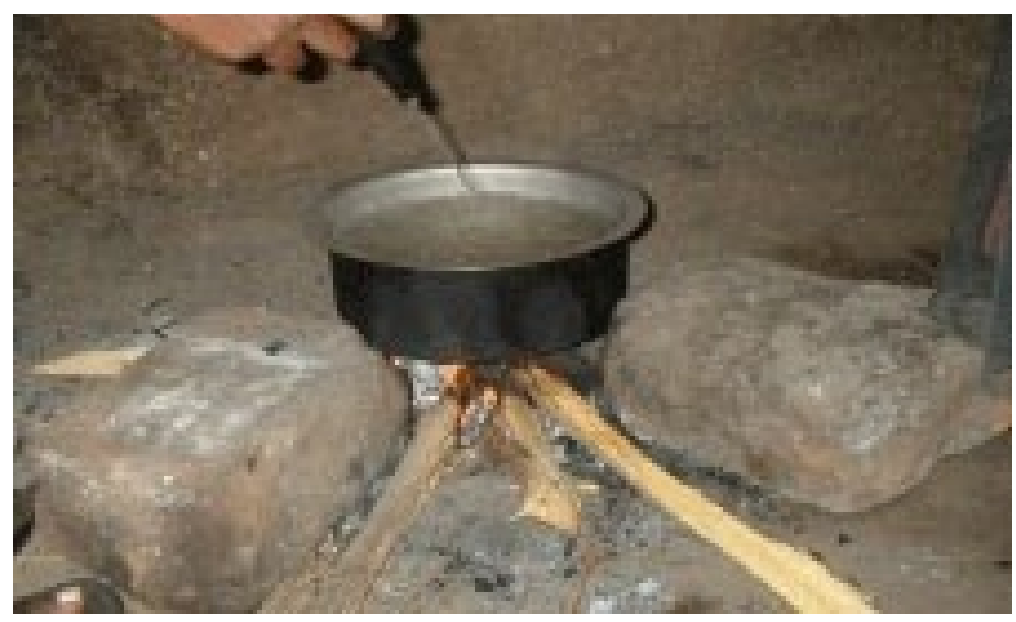

Figure 1. Open fire stoves: 3-stone fire stove and metal.

\section{Charcoal metal stove:}

The stove consists of an upper combustion chamber that opens to the atmosphere but separated from the ash chamber by a set of metal strips for charcoal support and allow ash drop to the base of the lower chamber. The base chamber consists of an opening for removing ashes and also serves as air-inlets chamber. The top of the stove consist of 4 finger seating of the same chamber to accommodate different size of pot. The combustion chamber is $15 \mathrm{~cm}$ wide and $23 \mathrm{~cm}$ high.

\section{Sawdust/rice husk stove:}

The sawdust or rice husk stove is circular in shape, and is made of light metal and consists of the combustion chamber, the top and base section. There is an opening at the top for loading sawdust into the combustion chamber and another opening at the base which serves as air inlets and for ashes removal. There are 3 pot rest of the same size to accommodate different pot sizes. The diameter of the combustion chamber is $14 \mathrm{~cm}$ and its height is $16 \mathrm{~cm}$.

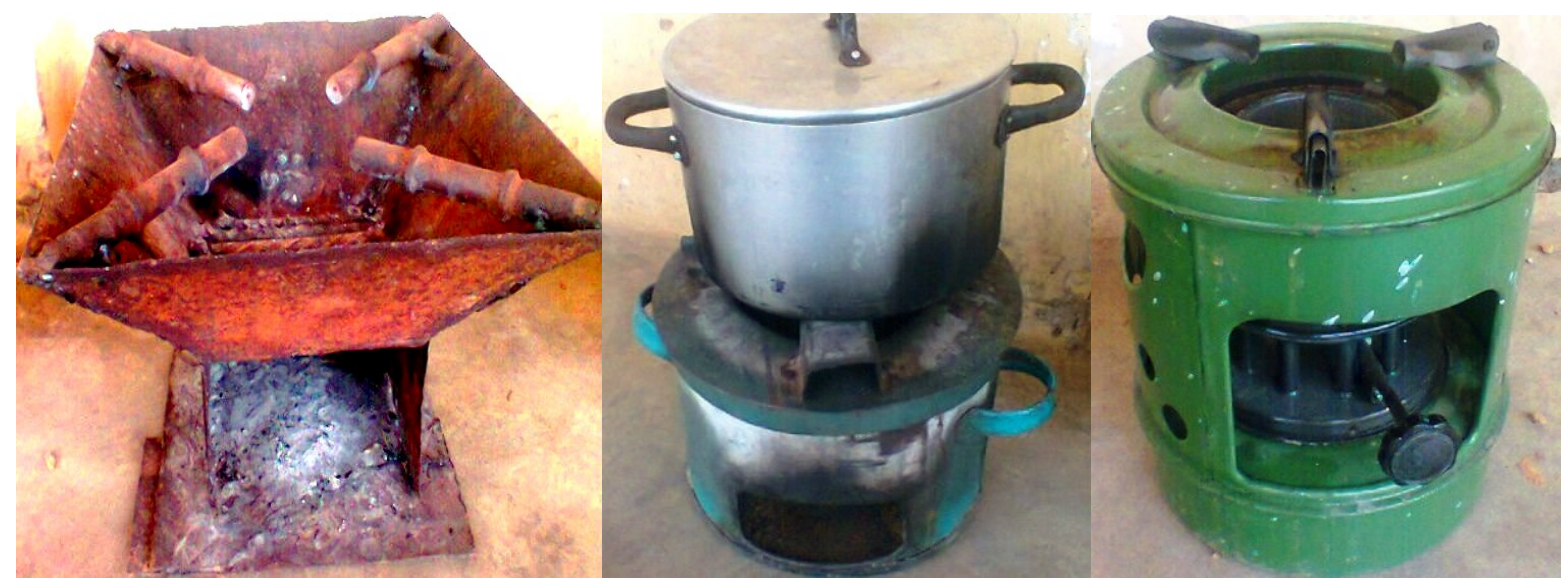

Figure 2. Test stoves: a) Charcoal, b) Sawdust / rice husk, c) kerosene. 


\section{Kerosene stove:}

The kerosene stove used is the circular Butterfly brand stove with 6 wick carrier mechanism made of a light metal material. There are two sets of perforated screens for air circulation to support burning. The wicks/threads (six in number) extend to the kerosene reservoir for continuous supply of kerosene to the burning wick in the chimney. The stove burner has a diameter $9 \mathrm{~cm}$ and overall height of $21 \mathrm{~cm}$.

\section{B. Fuel Material Description}

Fuel material selection and storage were determined by material availability (the commonly used) in domestic cooking In order to minimize the variation that is potentially introduced by fuel characteristics, VITA's precautionary recommendations of 1985 was considered; the use of only wood (or other fuel) that has been thoroughly air-dried and an assumption of solid fuels fuel having different burning characteristics.

The firewood of $5 \mathrm{~cm}$ average diameter range and approx. $60 \mathrm{~cm}$ long was gathered from around the College farm, and sun dried to reduce their moisture content to below $10 \%$. The charcoal fuel used for the water boiling test was bought in the open market and sorted to obtain a uniform size, so as to get the same weight at $6 \%$ moisture content. The sawdust was collected at the carpentry dump site and dried under exclusive environment to $8-10 \%$ moisture content dry basis. 5-liters volume of kerosene was used for the test.

\section{Instrumentation}

Test materials utilized include a flat bottom aluminum cooking pot $21 \mathrm{~cm}$ in diameter and $12 \mathrm{~cm}$ high. A glass tube $100{ }^{\circ} \mathrm{C}$ range thermometer was used to determine variation in temperature; it is graduated in $76 \mathrm{~mm}$ immersion. A stopwatch was used to measure time taken by each stove to boil a measured quantity of water at different intervals. A Salter electronics weighing balance of $5 \mathrm{~kg}$ capacity and $\pm 1 \mathrm{~g}$ accuracy was used for material weighing. The experimental setups were conducted under open environment and closed environment. Where necessary, the stoves were aspirated /supplemented with a hand fan to provide enough air support for combustion especially under closed environment, but under open environment, minimal aspiration was required due to air flow.

\section{1. Methodology}

The tests were conducted under two varying atmospheric conditions; open and closed environments. The first test was carried out in an open shed environment after taking the measurement of the materials used such as, the initial weight of the stoves, the quantities of fuels introduced into their combustion chambers, $10 \mathrm{ml}$ of kerosene were sprinkled to initiate ignition, stopwatch was used to monitor the time taken per cycle of operation.

Second test was conducted in an enclosed environment, where wind does not affect the burning of the fuels, measurement were also taken, as done in the first test. The time taken by the fuels to burn last more than the one conducted in an open environment. Three methods of stove test according to Stewart (1987); water boiling test (WBT) and controlled cooking test (CCT) was implemented to simulate cooking conditions because materials utilized in the test.

In conducting the water boiling tests, the following procedures were taken:

1. Dry weights of experimental materials like pot and stove were taken and recorded.

2. The pot was filled with an initial known weight of water and the same weight was maintained throughout the course of the experiment. 
3. All test procedures utilized in WBT test was adopted in the test for the briquettes in each of the stoves.

4. Data was collected and analyzed.

\section{A. Water Boiling Test}

The time of the day, the environmental conditions (ambient temperature) and the initial temperature of the water were noted. Thereafter the commencement of the test the temperature of the water was recorded at intervals of five (5) minutes until the moment the water came to a vigorous boil.

The pot was then removed from the stove and the fire immediately put out with the help of dry sand. The final weight of the remaining water, charcoal and the final temperature of water were then measured and recorded. The tests were carried out between $24^{\text {th }}$ of November and $7^{\text {th }}$ of December, 2011 starting at about 10am each day.

\section{B. Controlled Cooking Test (CCT)}

Controlled cooking test (CCT) was carried out using food items such as rice and yam (discorea rotundata). The performance characteristics of traditional stoves were compared with that of three stone fire stove and kerosene stove. Mass of the fuel was measured, and stacked inside the internally lined stove and Ignited. The first experiment was carried out using yam the pot containing water and yam was placed on the glowing fuel and left to cook. When the cooking was properly done, the mass of the cooked yam and time to achieve cooking were recorded with the aid of a stopwatch. Also, the mass of the fuel remaining after cooking was also recorded. The process was repeated using rice and beans respectively.

\subsection{Methods of data analysis}

The procedure and formulae employed in the calculation of parameters were based on the approach used by FAO (1990), Ahuja et al., (1997), Olorunisola (1999), and Kuti (2003).

\section{Performance Test Indicators}

a. Burn Rate $\left(R_{c b}\right)$ : This determines the rate at which a certain mass of fuel is combusted in air. This is a measure of the rate of wood consumption while bringing water to a boil. It is calculated by dividing the equivalent dry wood consumed by the time of the test. This is also used to calculate heat transfer efficiency, $\eta_{t h}(\%)$.

$$
\mathrm{r}_{\mathrm{cb}}=\mathrm{f}_{\mathrm{cd}} /\left(\mathrm{t}_{\mathrm{cd}}-\mathrm{t}_{\mathrm{cd}}\right) \ldots \ldots \ldots \ldots . . . .1
$$

The burn rate in $(\mathrm{Kg} / \mathrm{hr}$ ) can also be calculated using equation stated below (Ahuja et al., (1997)

$$
F=\eta_{t h}=\frac{1}{t} * 100 \frac{W_{i}-W_{f}}{100+m} \ldots \ldots \ldots . . . .2
$$

b. Thermal efficiency $\left(\eta_{t h}\right)$ : Thermal efficiency is a measure of the proportion of the total energy which is gainfully employed in any thermodynamic system. This is a ratio of the work done by heating and evaporating water to the energy consumed by burning wood. According to Clarke (1985) the thermal efficiency of a cooking stove depends largely on how well the heat generated is transferred from the hot gas of the fuel line to the pot or vessel on the stove (convective heat transfer). It is calculated as follows: 


$$
\eta_{t h}(100 \%)=\frac{\left(P_{c i}-P_{f}\right) *\left(T_{c l}-T_{c i}\right)+2260 * W_{c v}}{f_{c d} * L H V} \ldots \ldots \ldots . . .3
$$

The thermal efficiency is also related to the percentage heat utilized (PHU) given by:

$$
\eta_{t h}(100 \%)=\text { BurnRate }^{*} \text { PHU } \ldots \ldots \ldots . . . . .4
$$

where PHU is defined by

$$
P H U=\frac{m_{w} C_{p}\left(T_{b}-T_{o}\right)+m_{c} L}{m_{f} E_{f}} 100 \% \ldots \ldots \ldots \ldots . .5
$$

The numerator gives the net heat supplied to the water while the denominator gives the net heat liberated by the fuel.

where

$m_{w}=$ Mass of water in the pot $(\mathrm{kg})$;

$C_{p}=$ Specific heat of water $(\mathrm{kJ} / \mathrm{kg} \mathrm{K})$;

$T_{o}=$ Initial temperature of water $(\mathrm{K})$;

$T_{b}=$ Boiling Temperature of the water $(\mathrm{K})$;

$m_{c}=$ Mass of water evaporated $(\mathrm{kg})$;

$L=$ Latent heat of evaporation $(\mathrm{kg})$;

$m_{f}=$ mass of fuel burnt $(\mathrm{kg})$;

$E_{f}=$ Calorific value of the fuel $(\mathrm{kJ} / \mathrm{kg})$;

c. Specific Fuel Consumption: This is defined as the amount of solid fuel equivalent used in achieving a defined task divided by the weight of the task. It can be expressed as:

$$
S F C=\frac{\text { Mass of Consumed Fuel }\left(f_{c d}\right)}{\text { Total mass of cooked food }\left(P_{c f-P)}\right.} \ldots \ldots \ldots . . . .5
$$

According to Olorunnisola (1999), the specific fuel consumption (SFC) and the time (T) spent to cook $1 \mathrm{~kg}$ of food were examined from the data.

d. Time spent in cooking per kilogram of cook food:

$$
T_{s}=\frac{\text { Total time spent in cooking }\left(T_{t s}\right)}{\text { Total Weight of cooked food }\left(T_{w c}\right)}(\mathrm{hr} / \mathrm{kg}) \ldots \ldots \ldots \ldots . .6
$$

\section{RESULTS AND DISCUSSION}

The mean of results of the water boiling test and the controlled cooking tests under varying environmental conditions were presented below. The weight of material use and consumed by each stove are represented in Table 1. 
Table 1. Weight of Materials Used and Consumed in Each Stove.

\begin{tabular}{|c|c|c|c|c|}
\hline $\begin{array}{c}\text { Parameters } \\
\text { Rice (Yam) }\end{array}$ & $\begin{array}{c}\text { Sawdust } \\
\text { Stove }(\mathrm{Kg})\end{array}$ & $\begin{array}{c}\text { Charcoal } \\
\text { Stove } \\
(\mathrm{Kg})\end{array}$ & $\begin{array}{c}\text { 3- Stone } \\
\text { Fire Stove } \\
(\mathrm{Kg})\end{array}$ & $\begin{array}{c}\text { Kerosene } \\
\text { Stove } \\
(\mathrm{Kg})\end{array}$ \\
\hline Initial mass of raw food & 0.88 & 0.88 & 0.88 & 0.88 \\
\hline Final mass of cooked food & $\begin{array}{c}2.38 \\
(2.45)\end{array}$ & $\begin{array}{c}2.40 \\
(2.35)\end{array}$ & $\begin{array}{c}2.39 \\
(2.33)\end{array}$ & $\begin{array}{c}2.39 \\
(2.55)\end{array}$ \\
\hline $\begin{array}{c}\text { Initial mass of fuel at start of } \\
\text { cooking }\end{array}$ & 1.09 & 1.05 & 2.6 & 0.8 \\
\hline $\begin{array}{c}\text { Final fuel weight at the end of } \\
\text { cooking }\end{array}$ & $\begin{array}{c}0.4 \\
(0.4)\end{array}$ & $\begin{array}{c}0.71 \\
(0.43)\end{array}$ & $\begin{array}{c}0.6 \\
(1.04)\end{array}$ & $\begin{array}{c}0.17 \\
(0.32)\end{array}$ \\
\hline Mass of consumed fuel & $\begin{array}{c}0.69 \\
(0.69)\end{array}$ & $\begin{array}{c}0.34 \\
(0.62)\end{array}$ & $\begin{array}{c}2.0 \\
(1.56)\end{array}$ & $\begin{array}{c}0.63 \\
(0.48)\end{array}$ \\
\hline
\end{tabular}

\section{1. Results of Water Boiling Tests (WBT)}

Table 2 shows the results of time variation for WBT under varying conditions. The results within the close bracket represent the enclosed environment situation.

Table 2. Time Variation for WBT under Open Environment and (Enclosed Environment).

\begin{tabular}{|c|c|c|c|c|}
\hline Types of Stoves & $\begin{array}{c}\text { Rice Husk } \\
\text { Stove } \\
\text { (mins) }\end{array}$ & $\begin{array}{c}\text { Charcoal } \\
\text { Stove(mins) }\end{array}$ & $\begin{array}{c}\text { Three Stand } \\
\text { Stove (mins) }\end{array}$ & $\begin{array}{c}\text { Kerosene } \\
\text { Stove } \\
\text { (mins) }\end{array}$ \\
\hline $\begin{array}{c}\text { Time spent before fuel reaches } \\
\text { steady burn rate }\end{array}$ & $2.32(2.43)$ & $3.25(7.23)$ & $2.40(3.35)$ & $-(2.52)$ \\
\hline $\begin{array}{c}\text { Time spent by each stove to } \\
\text { boil } 1.30 \mathrm{~kg} \text { of water at } \\
100^{\circ} \mathrm{C}\end{array}$ & $8.32(8.32)$ & $5.17(5.17)$ & $10.03(10.03)$ & $-(-)$ \\
\hline $\begin{array}{c}\text { Total time spent for total fuel } \\
\text { combustion }\end{array}$ & $54.22(122)$ & $87(105)$ & $41.32(48.22)$ & $90(125)$ \\
\hline
\end{tabular}

The stoves were used for water boiling test (WBT) and controlled cooking test (CCT) under closed and open environment in order to determine the time variation to raise water temperature to $100{ }^{\circ} \mathrm{C}$ and time taken for each stove to boil specific quantity of food. It was found that in a closed environment, it takes a shorter time to boil $1.30 \mathrm{~kg}$ of water and cook some quantity of food, and consumes little quantity of fuels, while in open environment it consumes a lot of fuel and more time to cook the food and boil $1.20 \mathrm{~kg}$ of water.

\section{2. Results of Control Cooking Tests (CCT)}

The controlled cooking tests (CCT) conducted under various conditions for two varieties of food; rice and yam respectively were presented in Tables $2 \& 3$. Table 3 presents the result of controlled cooking test (CCT) under controlled atmosphere. 
Table 3 provides the time variation for each stove in CCT under the close environment. From the table, the sawdust stove takes more time $(7.23 \mathrm{~min})$ to reach steady burn rate while kerosene and charcoal stoves spent lesser time to reach steady burn rates. Total time spent in burning off the fuel varies for each stove but maintain time range of 32-39 min. time spent in cooking rice and yam were as indicated in each operation.

Table 3. Time Variation for CCT under Enclosed Environment.

\begin{tabular}{|c|c|c|c|c|}
\hline Types of Stoves & $\begin{array}{c}\text { Sawdust } \\
\text { Stove (min) }\end{array}$ & $\begin{array}{c}\text { Charcoal } \\
\text { Stove (min) }\end{array}$ & $\begin{array}{c}\text { Three Stand } \\
\text { Stove (min) }\end{array}$ & $\begin{array}{c}\text { Kerosene } \\
\text { Stove (min) }\end{array}$ \\
\hline $\begin{array}{c}\text { Time spent before fuel } \\
\text { reaches steady burn rate }\end{array}$ & $7.23 \mathrm{mins}$ & $2.43 \mathrm{mins}$ & $3.35 \mathrm{mins}$ & $2.52 \mathrm{mins}$ \\
\hline $\begin{array}{c}\text { Total time spent for } \\
\text { cooking rice }\end{array}$ & $37.22 \mathrm{mins}$ & $32.10 \mathrm{~min}$ & $39.30 \mathrm{mins}$ & $36.10 \mathrm{mins}$ \\
\hline $\begin{array}{c}\text { Total time spent cooking } \\
\text { yam }\end{array}$ & $20.15 \mathrm{mins}$ & $18.4 \mathrm{mins}$ & $23.31 \mathrm{mins}$ & $19.53 \mathrm{mins}$ \\
\hline
\end{tabular}

Table 4 indicates test results for cooking of rice and yam under enclosed environment. From the test results, charcoal burns more rapidly than sawdust and kerosene and hence heated up the water/food faster due to the passage of conventional airflow within the loosely packed materials in the combustion chamber (Segun et al., 2010). The rate of combustion of sawdust is generally slow and produces a lot of smoke because of inadequate air for complete combustion.

Table 4. CCT for Rice (Yam) under Enclosed Environment.

\begin{tabular}{|c|c|c|c|c|}
\hline Types of Stoves & $\begin{array}{c}\text { Sawdust } \\
\text { Stove }(\mathrm{Kg})\end{array}$ & $\begin{array}{c}\text { Charcoal } \\
\text { Stove }(\mathrm{Kg})\end{array}$ & $\begin{array}{c}\text { 3- Stand } \\
\text { Stove }(\mathrm{Kg})\end{array}$ & $\begin{array}{c}\text { Kerosene } \\
\text { Stove }(\mathrm{Kg})\end{array}$ \\
\hline Initial weight of the stove & 1.51 & 4.10 & - & 1.10 \\
\hline Initial weight of fuel & 1.09 & 1.05 & 2.6 & 0.8 \\
\hline Initial weight of stove + fuel & $\begin{array}{c}2.6 \\
(2.6)\end{array}$ & $\begin{array}{c}5.15 \\
(5.15)\end{array}$ & $\begin{array}{c}2.6 \\
(2.6)\end{array}$ & $\begin{array}{c}1.9 \\
(1.9)\end{array}$ \\
\hline Initial weight of the pot & 1.08 & 1.08 & 1.08 & 1.08 \\
\hline Quantity of water added to & $\begin{array}{c}0.9 \\
\text { pot }\end{array}$ & $\begin{array}{c}0.9 \\
(0.6)\end{array}$ & $\begin{array}{c}0.9 \\
(0.6)\end{array}$ & $\begin{array}{c}0.9 \\
(0.6)\end{array}$ \\
\hline Initial mass of raw rice $(\mathrm{kg})$ & $\begin{array}{c}0.88 \\
(0.88)\end{array}$ & $\begin{array}{c}0.88 \\
(0.88)\end{array}$ & $\begin{array}{c}0.88 \\
(0.88)\end{array}$ & $\begin{array}{c}0.88 \\
(0.88)\end{array}$ \\
\hline Weight of the pots +rice & $\begin{array}{c}1.96 \\
(2.33)\end{array}$ & $\begin{array}{c}1.96 \\
(2.33)\end{array}$ & $\begin{array}{c}1.96 \\
(2.33)\end{array}$ & $\begin{array}{c}1.96 \\
(2.33)\end{array}$ \\
\hline Weight of rice after boiling & $\begin{array}{c}2.38 \\
(2.45)\end{array}$ & $\begin{array}{c}2.40 \\
(2.35)\end{array}$ & $\begin{array}{c}2.39 \\
(2.33)\end{array}$ & $\begin{array}{c}2.39 \\
(2.55)\end{array}$ \\
\hline
\end{tabular}




\begin{tabular}{|c|c|c|c|c|}
\hline $\begin{array}{c}\text { Stove weight after } \\
\text { combustion }\end{array}$ & $\begin{array}{c}2.20 \\
(2.20)\end{array}$ & $\begin{array}{c}4.72 \\
(4.44)\end{array}$ & $\begin{array}{c}1.56 \\
(2.00)\end{array}$ & $\begin{array}{c}1.58 \\
(1.73)\end{array}$ \\
\hline \multirow{2}{*}{ Fuel weight after combustion } & 0.4 & 0.43 & 1.04 & 0.32 \\
& $(0.4)$ & $(0.71)$ & $(0.6)$ & $(0.17)$ \\
\hline \multirow{2}{*}{ Weight of fuel consumed } & 0.69 & 0.62 & 1.56 & 0.48 \\
& $(0.69)$ & $(0.34)$ & $(2.0)$ & $(0.63)$ \\
\hline
\end{tabular}

The time spent in cooking per kilogram of food and the result is presented in Table 5 below. Relatively, the time spent in cooking $1 \mathrm{Kg}$ of food; rice (yam) is not significantly different in all the stoves (maximum $0.75(044) \mathrm{kg} / \mathrm{hr}$ for 3 -stone stove and minimum 0.61 $(0.35) \mathrm{hr} / \mathrm{kg}$ for charcoal). The practical implication of this result is that lesser quantity of charcoal would be required to cook the same quantity of food on the charcoal stove than the open fire stove.

Table 5. Performance Evaluation of Each Stove.

\begin{tabular}{|c|c|c|c|c|}
\hline \multicolumn{5}{|c|}{ Cooking Duration for Rice (yam) (hrs) } \\
\hline Parameters & $\begin{array}{c}\text { Sawdust } \\
\text { Stove }\end{array}$ & $\begin{array}{c}\text { Charcoal } \\
\text { Stove }\end{array}$ & $\begin{array}{c}\text { 3- Stone } \\
\text { Fire Stove }\end{array}$ & $\begin{array}{c}\text { Kerosene } \\
\text { Stove }\end{array}$ \\
\hline $\begin{array}{c}\text { Total time spent in cooking } \\
\text { rice }\end{array}$ & $\begin{array}{c}37.22 \mathrm{mins} \\
(0.62 \mathrm{hr})\end{array}$ & $\begin{array}{c}32.10 \mathrm{mins} \\
(0.54 \mathrm{hr})\end{array}$ & $\begin{array}{c}39.30 \mathrm{mins} \\
(0.66 \mathrm{hr})\end{array}$ & $\begin{array}{c}36.10 \mathrm{mins} \\
(0.60 \mathrm{hr})\end{array}$ \\
\hline $\begin{array}{c}\text { Total time spent in cooking } \\
\text { yam }\end{array}$ & $\begin{array}{c}20.15 \mathrm{mins} \\
(0.34 \mathrm{hr})\end{array}$ & $\begin{array}{c}18.4 \mathrm{mins} \\
(0.31 \mathrm{hr})\end{array}$ & $\begin{array}{c}23.31 \mathrm{mins} \\
(0.39 \mathrm{hr})\end{array}$ & $\begin{array}{c}19.53 \mathrm{mins} \\
(0.33 \mathrm{hr})\end{array}$ \\
\hline $\begin{array}{c}\text { Time spent/kg of cooked } \\
\text { food (hr/Kg) }\end{array}$ & $\begin{array}{c}0.71 \\
(0.39)\end{array}$ & $\begin{array}{c}0.61 \\
(0.35)\end{array}$ & $\begin{array}{c}0.75 \\
(0.44)\end{array}$ & $\begin{array}{c}0.68 \\
(0.38)\end{array}$ \\
\hline $\begin{array}{c}\text { Ave. time spent/kg of cooked } \\
\text { food }\end{array}$ & 0.55 & 0.48 & 0.60 & 053 \\
\hline
\end{tabular}

\section{3. Specific fuel consumption and thermal efficiency}

The data collected were used in calculating the specific fuel consumption (SFC) and thermal efficiency presented in Table 6 below. The results show that the sawdust stove, three stand firewood stoves, and charcoal stove and kerosene stoves has thermal efficiencies of $32.76 \%, 64.38 \%, 26.06 \%$ and $61.03 \%$ and average specific fuel consumptions of 0.54 , $0.48,0.60$ and 0.55 respectively. Stove researchers have reported that standard, traditional charcoal stoves use about $2 \mathrm{~kg}$ of charcoal fuel per family per day (Granderson et al., 2009). 
Table 6. Performance Evaluation of Each Stove.

\begin{tabular}{|c|c|c|c|c|}
\hline Parameters & $\begin{array}{c}\text { Sawdust } \\
\text { Stove }\end{array}$ & $\begin{array}{c}\text { Charcoal } \\
\text { Stove }\end{array}$ & $\begin{array}{c}\text { 3- Stone } \\
\text { Fire Stove }\end{array}$ & $\begin{array}{c}\text { Kerosene } \\
\text { Stove }\end{array}$ \\
\hline $\begin{array}{c}\text { Specific fuel consumption } \\
\text { (SFC) }\end{array}$ & $\begin{array}{c}0.68 \\
(0.39)\end{array}$ & $\begin{array}{c}0.61 \\
(0.35)\end{array}$ & $\begin{array}{c}0.75 \\
(0.44)\end{array}$ & $\begin{array}{c}0.72 \\
(0.38)\end{array}$ \\
\hline Thermal Efficiency (\%) & 52.64 & 64.38 & 34.56 & 54.38 \\
\hline
\end{tabular}

Therefore, the efficiencies of combustion and heat transfer are quite high for a charcoal stove and a biomass stove, by this measure, the specific fuel consumption value of the 3 -stone stove is lesser than all other stoves. Charcoal stove have lower specific fuel consumption values indicating less fuel consumption and higher thermal efficiency. This indicates a better performance when compared to other stove such as kerosene stove which has thermal efficiency of $54.38 \%$.

\section{CONCLUSIONS}

From the test results, the time spent in cooking $1 \mathrm{Kg}$ of rice/ (yam) is significantly different in all the stoves (maximum $0.75(0.44) \mathrm{kg} / \mathrm{hr}$ for 3 -stone stove and minimum 0.61 $(0.35) \mathrm{hr} / \mathrm{kg}$ for charcoal). The quantity of fuel utilization also differs for instance lesser quantity of charcoal would be required to cook the same quantity of food on the charcoal stove than the open fire stove. The results indicates that charcoal burns more rapidly than other stoves indicating a higher thermal value and hence heated up the water/food faster due to the passage of conventional airflow within the loosely packed materials in the combustion chamber (Segun et al., 2010). The rate of combustion of sawdust is generally slow and produces a lot of smoke because of inadequate air for complete combustion. The results equally show that the specific fuel consumption value of the charcoal stove is lesser than all other stoves. The 3-stone stove have higher specific fuel consumption values indicating more fuel consumption and lower thermal efficiency. The practical implication of this result is that the stoves have differing SFC value for different foods. This indicates a better performance when compared to other stove such as kerosene stove which has thermal efficiency of $64.38 \%$.

\section{References}

[1] Ahuja D. F., Joshi V., Smith K. R., Venkataranman C. (1997). “Thermal Performance and Emission Characteristic of Unvented Biomass-Burning Cookstove. Standard Methods for Evaluation. Biomass, 10:12.

[2] Boutete M. (1981). Testing the efficiency of wood burning cook stove provisional international standards. VITA, Int Raimer Maryland, pp. 35-40.

[3] Clarke R. (1985). "Wood-stove Dissemination". Proceeding of the Conference held at Wolfheze, The Netherlands. Intermediate Technology Publications, 9 king Street, London. Pp. 97-102. 
[4] FAO (1990). "The Briquetting of Agricultural Waste for Fuel Environment and Energy". 1(2): $25-31$.

[5] Granderson J., Sandhu J. S., Vasquez D., Ramirez E., Smith K. R., (2009). Fuel use and Design analysis of improved wood burning cookstoves in the Guatemalan Highlands. Biomass \& Bioenergy, 33: 306-315.

[6] Kuti O. A., (2003). Evaluation of composite sawdust briquette as a high grade fuel for domestic cooking. M.Eng Thesis, Federal University of Technology, Akure, Nigeria.

[7] Olorunisola A. O. (1999). "Efficiency of two Nigerian Cooking Stoves in Handling CornCob Briquettes". Nigerian Journal of Renewable Energy, 7(1 \&2); 31-34.

[8] Bello R. S., Adegbulugbe T. A., Onyekwere P. S. N., (2010). Comparative Study on Utilization of Charcoal, Sawdust and Rice Husk in heating oven. Agricultural Engineering International: the CIGR Journal of Scientific Research and Development. Agric Eng Int: CIGR Journal Open access at http://www.cigrjournal.org Vol. 12, No.2 29, Volume XII, June, 2010 March, 2010.

[9] Stewart W. (198). Improved Wood, Waste and Charcoal Burning Stoves. A Practical Manual. Intermediate Technology Publications, Covent Garden, London, UK.

[10] Stout B. A., Best G. (2001). Effective energy use and climate change: Needs of rural areas in developing countries. Invited overview. Vol. III.

[11] VITA (1985). Testing the Efficiency Of Wood-Burning Cookstoves: Provisional International Standards. 1985, Volunteers in Technical Assistance: Arlington, VA p. 76. 